\title{
Practical issues in measuring the anticoagulant effect of direct oral anticoagulants
}

\author{
Violeta Dopsaj ${ }^{1,2}$ \\ ${ }^{1}$ University of Belgrade - Faculty of Pharmacy, Department of Medical Biochemistry, \\ Belgrade 11221, Serbia \\ ${ }^{2}$ Center of Medical Biochemistry, Clinical Center of Serbia, Belgrade 11000, Serbia
}

Corresponding author: Violeta Dopsaj, e-mail: violeta.dopsaj@gmal.com

\begin{abstract}
Summary
The classical oral anticoagulants are increasingly being replaced in clinical practice by new antithrombotic drugs, which act by enabling direct inhibition of coagulation factor IIa (FIIa) or factor Xa (FXa). These drugs have multiple acronyms, including NOACs (new, non-vitamin $\mathrm{K}$ antagonist) or DOACs (direct oral anticoagulants), and currently include dabigatran (FIIa inhibitor), and rivaroxaban, apixaban, and edoxaban (FXa inhibitors). These drugs are approved for stroke prevention in patients with non-valvular atrial fibrillation and the prevention and treatment of venous thromboembolism. The "mantra" that DOACs do not require laboratory monitoring is not entirely correct because laboratory testing for drug effects is needed in many situations, because they influence hemostasis tests and in situations in which urgent measurement of DOACs is required. This should be very important to consider in the clinical situation for numbers of indications and increasing numbers of patients on DOACs therapy. The main aim of this article is to provide practical issues to general laboratory testing for DOACs, as well as to help avoid diagnostic errors associated with hemostasis testing. The assays for DOAC quantification must be available in medical centers on a whole day basis, to facilitate optimal drug management in conditions when things go wrong or in urgent cases of immediate reversal of anticoagulation or appropriate administration of a specific antidote.
\end{abstract}

Key Words: DOACs, rivaroxaban, dabigatran, apixaban, laboratory monitoring 


\section{Introduction}

The direct oral anticoagulants (DOACs) including dabigatran (inhibits thrombin), rivaroxaban, apixaban, and edoxaban, (inhibits factor $\mathrm{Xa}$ ) are increasingly replacing classic anticoagulant drugs vitamin $\mathrm{K}$ antagonists and heparin preparations for the following indications: for the prevention of stroke and systemic embolism in patients with non-valvular atrial fibrillation, for the primary prevention of venous thromboembolic events in patients undergoing elective surgery, for the treatment of deep vein thrombosis and pulmonary embolism, as well as for the prevention of these conditions reoccurring in adults $(1,2)$. DOACs were introduced to overcome the limitations of Vitamin $\mathrm{K}$ antagonists (the narrow therapeutic range, inter- and intra-individual variability of anticoagulant response as a result of environmental and genetic factors, laboratory monitoring for dose adjustment, drug-drug interactions).

DOACs have been tested in randomized clinical trials and proved safe and effective when administered at a fixed dose (based on patient characteristics) without the need for dose adjustment based on laboratory testing. Although the DOACs do not require routine coagulation monitoring, there are several situations in which DOACs anticoagulant activity should be measured (1). Nevertheless, measurements of their anticoagulant activity are useful in a specific situation or a specific patient, including 1) time before surgery or invasive procedure; 2) in case of adverse events (thrombosis or hemorrhage); 3 ) patients with renal/liver disease; 4) whenever a possible interaction with other drugs is suspected; 5) in patients with extreme bodyweight; 6) to assess adherence to the therapy; 7) before thrombolytic therapy in patients with stroke (3-6). Likewise, when urgent anticoagulation is required, DOACs measurement might be useful to ensure their appropriate administration and to prevent overuse of these expensive medications (7). The recommendations and consensus documents on laboratory testing of DOACs are consistent and guide clinicians in the decision-making process $(4,8-10)$. Due to the high inter-individual variability in the response to DOAC, the assessment of DOAC concentrations cannot be based on the last intake (time-based approach). The reliable assays are established on a concentration-based approach but they must be readily available 24h/day, easy to perform with short turnaround time, and accurate for measurement of a wide range of concentrations $(11,12)$.

Since DOACs are removed from the circulation through the kidney or the liver, their use in patients with severe renal insufficiency or chronic liver disease is usually contraindicated. Much debate has been done over the last decade on the role that clinical laboratories may have in the management of patients on DOACs. Recommendations from regulatory authorities (FDA, EMA) have not been issued. Prescribing these drugs by clinicians is based on recommendations issued by scientific societies when available, but there is no uniform application. DOACs testing is poorly used because hospitals are not equipped with tests on different commercial platforms (12). 


\section{Laboratory testing for the DOACs}

While the relationship between DOACs levels and the clinical outcomes have been widely investigated and published, therapeutic ranges have not yet been defined (13). Instead of therapeutic ranges, it is much useful to inspect the concept of the "on-therapy" range (interval marked by the 5 th percentile trough concentration and the 95 th percentile peak concentration). Drug levels lower than the 5 th percentile trough concentration could be considered as in the "below on-therapy" range, since those greater than the 95th percentile peak concentration may be considered to be "above on-therapy". In this concept of the "on-therapy" range, the patients in steady-state plasma DOAC concentrations will have drug levels that fall within the on-therapy range at any time during treatment (14).

The gold standard method for measurement of plasma DOACs concentrations (rivaroxaban, dabigatran, apixaban, edoxaban) is liquid chromatography/tandem mass spectrometry (LC-MS/MS) which requires expensive and sophisticated instrumentation, as well as skilled personnel, conditions that are unavailable to most routine clinical laboratories (15). Long turnaround time for test results would also make the method unsuitable for urgent testing in emergencies when you need to get a result within 30 minutes. Therefore, to provide both routine and urgent assessment of DOACs, clinical laboratories are in a need of more practical tests.

\section{Routine coagulation assays and DOACs}

When considering the determination of anticoagulants in the laboratory, two concepts should be distinguished - monitoring and measuring. In the main "monitoring" concept the level of anticoagulation is assessed by dose adjustment based on results from laboratory testing. This concept is applied for vitamin $\mathrm{K}$ antagonists and unfractionated heparin monitoring therapy, using prothrombin time (PT) and activated partial thromboplastin time (aPTT). Monitoring anticoagulation with low molecular weight heparin (LMWH) does not require routine laboratory testing with anti-factor Xa assay, except for a special group of patients. Another concept is "measuring", where the assessment of the level of anticoagulation or drug concentration in the blood is determined after administration of a fixed-dose. Although the "measuring" concept has been applied to DOACs, that does not mean laboratory testing is not necessary and useful in specific situations (12).

The first laboratory testing in patients on DOACs included the routine coagulation assays - PT, aPTT, and thrombin time (TT), which are widely used in most clinical laboratories. PT, a PTT, and TT are tests that measure the activities of coagulation factors and overall function of the whole coagulation pathways - extrinsic, intrinsic, and common. The time of clot formation in these functional global tests can be a change in several clinical conditions, including liver disease, acquired/congenital factor 
deficiencies, or the presence of antiphospholipid antibodies (15). Determination of PT, aPTT, and TT in patients on DOACs should only be used as a screening test that is aimed to confirm the existence or absence of an anticoagulant effect. These assays also cannot measure DOACs anticoagulant effect reliably, because of their poor sensitivity and specificity and lack of optimal dose-response relationships for monitoring DOACs (16).

The results of PT, aPTT, and TT are dependent on the type of DOACs, the composition of commercial reagents, and the type of coagulometer used for testing. Likewise, the limitation of PT and aPTT are associated with their considerably different levels of responsiveness to increasing DOACs concentrations. The main fact is that normal PT and PTT don't exclude DOAC activity and their prolongation doesn't confirm DOACs action. A normal aPTT probably excludes above on-therapy concentrations, but not necessarily on-therapy or below on-therapy levels. PT is usually more sensitive than aPTT for rivaroxaban, and normal PT probably excludes above on-therapy levels of rivaroxaban and edoxaban. For apixaban, PT and aPTT have normal values and are not useful. For dabigatran PT and aPTT should not be used, only a normal TT excludes clinically relevant existence of the drug in circulation (17). Furthermore, unclottable prolongation of TT may occur in patients taking $150 \mathrm{mg}$ dabigatran twice daily, because of the excessive responsiveness. As a result of all the above, the use of PT or PTT to evaluate DOACs activity could cause misinterpretations of routine coagulation assays, especially by non-expert clinicians. Consequently, only a normal TT excludes clinically relevant levels of dabigatran $(18,19)$. The effect of dabigatran, rivaroxaban, apixaban, and edoxaban on global and specific coagulation assays to below, within, and above typical 'on-therapy' range is shown in Table I.

\section{Specific assays for DOACs}

The DOACs anticoagulant effect should only be qualitatively validated with routine coagulation tests, PT, aPTT, and TT, but these tests should not be used to adjust doses and dosing intervals. The specific, second-line tests for DOACs which can be performed in specialized coagulation laboratories include diluted thrombin time (dTT), ecarin clotting time (ECT), and anti-Xa assays.

The chromogenic anti-factor Xa assay can be used for the quantification of anticoagulant DOACs-factor Xa inhibitors activity (rivaroxaban, apixaban, and edoxaban). The dTT and ECT assays should be applied to measure the dabigatran anticoagulant effect. Direct measurement of drug plasma concentrations with LC-MS/MS is possible in a small number of laboratories and cannot be used in making therapeutic decisions $(12,20)$.

Diluted thrombin time (dTT). TT is a coagulometric test very sensitive to dabigatran and the anticoagulant effect could be measured only with diluted TT. Dilution of patient plasma in dTT test provides an adequate response to dabigatran, with a clotting time prolongation dependently related to dabigatran concentrations. For example, in a patient 
taking dabigatran $150 \mathrm{mg}$ twice daily, twofold dTT prolongation over the normal clotting time can be detected, thus the clotting time prolongation of dTT is proportional to the inhibitory activity of dabigatran. The dTT test is commercially available from different manufacturers $(12,19)$. The lowest concentration of DOACs that allows a safe surgical or invasive procedure is unknown and should be derived only from clinical trials. Most recommendations advise that DOAC levels of less than $50 \mathrm{ng} / \mathrm{ml}$ can be considered relatively safe, and this cutoff should be pragmatically adopted (12).

Table I Effect of Dabigatran, Rivaroxaban, Apixaban and Edoxaban on routine and specific coagulation assays to below, within, and above typical 'on-therapy' range (18)

Tabela I Uticaj dabigatrana, rivaroksabana, apiksabana i edoksabana na rutinske i specifične koagulacione testove u odnosu na očekivani terapijski opseg (unutar, ispod i iznad opsega) (18)

\begin{tabular}{|c|c|c|c|c|c|}
\hline & $\begin{array}{l}\text { Relationship } \\
\text { to expected } \\
\text { 'on therapy' } \\
\text { range }\end{array}$ & Dabigatran & Rivaroxaban & Apixaban & Edoxaban \\
\hline \multirow{3}{*}{ aPTT } & Below & Normal/Prolonged & Normal limits & Normal limits & Normal limits \\
\hline & Within & Prolonged & Normal/Prolonged & Normal/Prolonged & Normal limits \\
\hline & Above & Prolonged & Normal/Prolonged & Prolonged & Normal/Prolonged \\
\hline \multirow{3}{*}{ PT } & Below & Normal limits & Normal limits & Normal limits & Normal limits \\
\hline & Within & Normal/Prolonged & Normal/Prolonged & Normal/Prolonged & Normal/Prolonged \\
\hline & Above & Normal/Prolonged & Normal/Prolonged & Normal/Prolonged & Normal/Prolonged \\
\hline \multirow{3}{*}{ TT } & Below & Prolonged & Normal & Not indicated & Not indicated \\
\hline & Within & Prolonged/Out of range & Normal & Not indicated & Not indicated \\
\hline & Above & Prolonged/Out of range & Normal & Not indicated & Not indicated \\
\hline \multirow{3}{*}{$\begin{array}{l}\text { Dilute } \\
\text { TT }\end{array}$} & Below & Normal/Prolonged & Not indicated & Not indicated & Not indicated \\
\hline & Within & Prolonged & Not indicated & Not indicated & Not indicated \\
\hline & Above & Prolonged & Not indicated & Not indicated & Not indicated \\
\hline \multirow{3}{*}{ Anti-Xa } & Below & Not indicated & Normal/Increased & Normal/Increased & Normal/Increased \\
\hline & Within & Not indicated & Increased & Increased & Increased \\
\hline & Above & Not indicated & Increased & Increased & Increased \\
\hline
\end{tabular}


Ecarin clotting time (ECT). ECT based on ecarin, a snake venom extract, able to convert prothrombin into thrombin, is another commercial assay that can be used for dabigatran. The inhibition by dabigatran can be measured by a chromogenic substrate or clotting method $(18,21)$. For dabigatran, a concentration of $30 \mathrm{ng} / \mathrm{mL}$ is considered safe for surgery in the case of intervention with bleeding risk. Therefore, if the concentration is higher than $30 \mathrm{ng} / \mathrm{mL}$, the intervention should be delayed. The use of specific coagulation tests may also guide the clinician in the use of idarucizumab, the dabigatran antidote. It has been suggested that if the plasma concentration of dabigatran is below 50 $\mathrm{ng} / \mathrm{mL}$ in a bleeding patient, a reversal agent should not be administered (22).

\section{Anti-factor Xa assays (Anti-Xa)}

The Anti-Xa test is used as a method of choice for measuring anti-factor Xa activity in patients treated with unfractionated (UFH) or LMWH. Anti-factor Xa activity of DOACs (rivaroxaban, apixaban, or edoxaban), in a dose-dependent manner, can be measured by a specific chromogenic substrate $(23,24)$. The presence of clinically relevant plasma concentrations of anti-factor Xa inhibitors can be measured by an anti-Xa test, using plasma calibrators commercially available, mandatory for each specific DOAC. Plasma drug concentration derived from the calibration curve, acquire proper result interpretation in regards to the timing of drug intake. These tests are applied to various commercial coagulometers in clinical laboratories $(12,15)$. In practice, each laboratory requires the use of specific reagents, calibrators, and controls for each drug, and needs to implement at least three different tests for each of the currently available anti-Xa drugs. The laboratory professionals will also need to maintain the coagulation analyzer calibrated and monitored (by internal quality controls) for all these tests, perhaps 24 hours a day and 365 days a year, since urgent assessment may be required. That is why regulatory authorities should urgently approve the use of these assays for a patient on DOACs in special conditions, and guidelines on how and when to do DOAC testing should be urgently implemented in local hospitals $(25,26)$.

Recommendations for laboratory measurement of DOACs based on clinical objectives are shown in Table II. 
Table II Suggestions for laboratory measurement of DOAC based on clinical objective (25)

Tabela II Preporuke za laboratorijsko određivanje direktnih oralnih antikoagulanasa zasnovane na kliničkom cilju (25)

\begin{tabular}{|c|c|c|c|c|c|}
\hline \multirow[b]{2}{*}{ Drug } & \multicolumn{2}{|c|}{$\begin{array}{l}\text { Determine if drug levels are } \\
\text { present in Clinically relevant } \\
\text { Below On-therapy }\end{array}$} & \multirow{2}{*}{$\begin{array}{c}\text { Estimate } \\
\text { drug levels } \\
\text { within } \\
\text { On-therapy } \\
\text { range } \\
\begin{array}{c}\text { Suggested } \\
\text { test }\end{array} \\
\end{array}$} & \multicolumn{2}{|c|}{$\begin{array}{c}\text { Determine if drug levels are } \\
\text { present in Clinically relevant } \\
\text { Above On-therapy }\end{array}$} \\
\hline & $\begin{array}{c}\text { Suggested } \\
\text { test }\end{array}$ & Interpretation & & $\begin{array}{c}\text { Suggested } \\
\text { test }\end{array}$ & Interpretation \\
\hline Dabigatran & TT & $\begin{array}{l}\text { Normal TT likely } \\
\text { excludes clinically } \\
\text { relevant drug level }\end{array}$ & $\begin{array}{c}\text { Dilute TT } \\
\text { ECT }\end{array}$ & $\begin{array}{l}\text { aPTT } \\
\text { dTT } \\
\text { ECT }\end{array}$ & $\begin{array}{c}\text { Normal aPTT likely } \\
\text { excludes excess drug } \\
\text { levels; } \\
\text { Only dTT, ECT is sutable } \\
\text { for quantitation }\end{array}$ \\
\hline Rivaroxaban & Anti-Xa & $\begin{array}{c}\text { Normal anti-Xa activity } \\
\text { likely excludes } \\
\text { clinically relevant drug } \\
\text { levels }\end{array}$ & Anti-Xa & $\begin{array}{c}\text { Anti-Xa } \\
\text { PT }\end{array}$ & $\begin{array}{l}\text { Normal PT likely excludes } \\
\text { excess drug levels; } \\
\text { Only anti-Xa is suitable } \\
\text { for quantitation }\end{array}$ \\
\hline Apixaban & Anti-Xa & $\begin{array}{c}\text { Normal anti-Xa activity } \\
\text { likely excludes } \\
\text { clinically relevant drug } \\
\text { levels }\end{array}$ & Anti-Xa & Anti-Xa & - \\
\hline
\end{tabular}

\section{General laboratory testing in patients on DOACs}

Laboratory monitoring in patients on DOACs is of great importance to guide appropriate anticoagulation therapy and ensure drug safety. DOACs are cleared from circulation by kidney (dabigatran $80 \%$, edoxaban $50 \%$, rivaroxaban $30 \%$, and apixaban $25 \%$, respectively) or liver (apixaban $75 \%$, rivaroxaban $66 \%$, edoxaban $50 \%$, dabigatran $20 \%$ ). Therefore, acute renal or liver impairment may also substantially impair the blood levels of all DOACs and expose the patients to a significant risk of overcoagulation or undercoagulation. (2,27). The most commonly used laboratory profile includes general laboratory tests for screening renal and hepatic function and assessing bleeding risk. The frequency of laboratory testing depends on individual patient characteristics (monthly or every 3-6 months) and include age, comorbidities, renal/liver function, and concurrent drug therapy. Baseline renal function testing is necessary before initiating therapy 
because all DOACs are partially eliminated through the kidneys. Renal function should be estimated based on serum creatinine ( $\mathrm{SCr}$ ) for creatinine clearance calculation (Cockcroft-Gault equation or estimated glomerular filtration rate (eGFR)). To ensure appropriate dosing and prevent bleeding complications periodical routine measuring of $\mathrm{SCr}$ is required (28). Because the rate of renal elimination varies among the different DOACs, fluctuations in renal function can potentially lead to considerable bleeding complications.

A laboratory analyzes of liver function assessment (aspartate aminotransferase (AST), alanine aminotransferase (ALT), bilirubin, alkaline phosphatase, PT) should be determined at the beginning of therapy and periodically afterwards, to detect any significant changes in hepatic function. Estimation of hepatic function is required yearly for healthy patients, while more frequent monitoring is necessary for patients with risk of liver disease (at least every 6 months). In addition to the data for monitoring liver function, the Child-Pugh scoring system could be helpful to predict mortality in patients with cirrhosis, using five clinical and laboratory criteria to categorize patients (serum bilirubin, serum albumin, ascites, neurological disorder, and prothrombin time) $(29,30)$. Measurement of the complete blood count (CBC) is essential at the baseline and during initiation of the DOACs therapy, at least yearly thereafter, or more repeatedly in patients with bleeding symptoms.

\section{Effect of direct oral anticoagulants on hemostatic parameters}

Hemostasis tests are often requested by clinicians during oral anticoagulation therapy, especially parameters for thrombophilia screening (antithrombin, protein $\mathrm{C}$, protein $\mathrm{S}$, activated protein $\mathrm{C}$ resistance, lupus anticoagulant, factor VIII). A large number of studies have shown that DOACs may be a reflection of inappropriate testing during anticoagulant therapy, resulting in misinterpretation of the results $(31,32)$. A recent check of clinical practice indicates that up to $1 / 3$ of samples destined for thrombophilia investigations are from patients on oral anticoagulant therapy, and thus is representing the high potential for diagnostic error. The proper timing of test orders for thrombophilia screening is very important, and whenever possible testing should be performed after discontinuation of the DOACs treatment (4-5 days) (35).

\section{Antithrombin}

If the patient is taking dabigatran and the target enzyme used for antithrombin measurement is thrombin, antithrombin activity will be overestimated, as thrombin activity will be inhibited not only by antithrombin but also by dabigatran. The same overestimation will occur when the anti-FXa drug is taken, and the target enzyme used for testing is FXa. The extent of overestimation could be such to mask the diagnosis in patients with congenital heterozygous antithrombin deficiency. To avoid these undesirable effects, laboratory testing for antithrombin in patients on dabigatran should 
be performed with methods using FXa as the target enzyme. Conversely, methods using thrombin as the target enzyme should be used for patients on anti-FXa drugs $(12,33)$.

\section{Lupus anticoagulants}

The interpretation of LA detection in patients taking DOACs using phospholipiddependent tests (aPTT and dRVVT) may be problematic. There are some reports in the literature on special procedures used to try to overcome the interference of DOAC on LA testing. However, considering the reagents and methods are not standardized, no procedure can be recommended for general use to search for LA in patients on DOAC. When the laboratory diagnosis of LA is strictly needed, temporarily switching the patient from DOAC to LMWH (if the brand used does not interfere with LA testing) could be a helpful alternative $(34,35)$.

The effects of DOACs on the hemostatic parameters are shown in Table III.

Table III Effects of direct oral anticoagulants on the results of hemostatic parameters (12)

Tabela III Uticaj direktnih oralnih antikoagulanasa na rezultate parametara hemostaze (12)

\begin{tabular}{|l|l|l|}
\hline Parameter & Effect & $\begin{array}{l}\text { Clinical significance } \\
\text { Risk for misdiagnosis }\end{array}$ \\
\hline Antithrombin activity & Overestimation & $\begin{array}{l}\text { Absence in antithrombin deficiency } \\
\text { False-negative }\end{array}$ \\
\hline Protein C activity & Overestimation & $\begin{array}{l}\text { Absence in PC deficiency } \\
\text { False-negative }\end{array}$ \\
\hline Protein S activity & Overestimation & $\begin{array}{l}\text { Absence in PS deficiency } \\
\text { False-negative }\end{array}$ \\
\hline Coagulation factors & Underestimation & $\begin{array}{l}\text { Factor deficiency } \\
\text { False-positive }\end{array}$ \\
\hline Fibrinogen & $\begin{array}{l}\text { Underestimation in } \\
\text { patients on dabigatran }\end{array}$ & $\begin{array}{l}\text { Hypofibrinogenemia } \\
\text { False-positive }\end{array}$ \\
\hline $\begin{array}{l}\text { Activated protein C } \\
\text { resistance (APC ratio) }\end{array}$ & Underestimation & $\begin{array}{l}\text { Absence of Factor V Leiden } \\
\text { False-negative }\end{array}$ \\
\hline $\begin{array}{l}\text { Lupus anticoagulants } \\
\text { (dRVVT) }\end{array}$ & $\begin{array}{l}\text { Difficult to interpret the } \\
\text { result }\end{array}$ & $\begin{array}{l}\text { Presence of LA } \\
\text { False-positive }\end{array}$ \\
\hline
\end{tabular}




\section{Summary}

Routine coagulation assays are widely available, rapid, and inexpensive but limited in their accuracy for measuring DOACs drug levels. Specific assays can accurately quantify the drugs however they are only available in specialized coagulation laboratories and are more expensive. In these circumstances, appropriate recommendations for DOACs laboratory testing include a combination of routine and second-line hemostasis testing in specific situations or specific patients.

\section{References}

1. Ageno W, Gallus AS, Wittkowsky A, et al. American College of Chest Physicians. Oral anticoagulant therapy: Antithrombotic Therapy and Prevention of Thrombosis, 9th ed: American College of Chest Physicians Evidence-Based Clinical Practice Guidelines. Chest. 2012; 41(Suppl. 2):e44S-88S.

2. Antonijevic et al. Dabigatran - Metabolism, Pharmacologic Properties and Drug Interactions (Review article). Current Drug Metabolism 2017; 18(7):1-14.

3. Heidbuchel H, Verhamme P, Alings M, et al. Updated European Heart Rhythm Association Practical Guide on the use of non-vitamin K antagonist anticoagulants in patients with non-valvular atrial fibrillation. Europace. 2015;17:1467-1507.

4. Pengo V, Crippa L, Falanga A, et al. Questions and answers on the use of dabigatran and perspectives on the use of other new oral anticoagulants in patients with atrial fibrillation. A consensus document of the Italian Federation of Thrombosis Center (FCSA). Thromb Haemost. 2011;106:868-76.

5. Baglin T. The role of the laboratory in treatment with new oral anticoagulants. Br J Haematol. 2013;163:160-7.

6. Tripodi A. The laboratory and the direct oral anticoagulants. Blood 2013;121:4032-5.

7. Pollack CV Jr, Reilly PA, Eikelboom J, et al. Idarucizumab for dabigatran reversal. N Engl J Med. 2015;6:511-20.

8. Dale BJ, Chan NC, Eikelboom JW. Laboratory measurement of the direct oral anticoagulants. Br J Haematol. 2016,172:315-36.

9. Bauer KA. Targeted anti-anticoagulants. N Engl J Med. 2015;373:569-71.

10. Brieger D, Curnow J. Anticoagulation: A GP primer on the new oral anticoagulants. Aust Fam Physician. 2014;43(5):254-59. 
11. Gouin-Thibault I, Delavenne X, Blanchard A, et al. Inter-individual variability in dabigatran and rivaroxaban exposure contribution of $\mathrm{ABCB} 1$ genetic polimorphisms and interaction with clarithromycin. J Thromb Haemost. 2017; 15:273-83.

12. Armando Tripodi, Simon Braham, Barbara Scimeca, Marco Moia, Flora Peyvandi. How and when to measure anticoagulant effects of direct oral anticoagulants? Practical issues. Arch Intern Med. 2018;128(6):379-85.

13. Gosselin RC, Adcock DM. The laboratory 2015 perspective on direct oral anticoagulant testing. J Throm Haemost. 2016;14:886-93.

14. Cuker A, Siegal DM, Crowther MA, Garcia DA. Laboratory measurement of the anticoagulant activity of the non-vitamin K antagonist oral anticoagulants. J Am Coll Cardiol. 2014;64(11):112839.

15. Tripodi A. The laboratory and the new oral anticoagulants. Clin Chem. 2013;59:353-62.

16. RC Gossselin, DM Adcock. The laboratory s 2015 perspective on dierect oral anticoagulant testing. $\mathrm{J}$ of Thrombosis and Haemostasis 2016;14(5):886-93.

17. Baglin T. The role of the laboratory in treatment with new oral anticoagulants. J Thromb Haemost. 2013;11(Suppl 1):8-112.

18. Samuelson BT, Cuker A, Siegal DM, Crowther M, Garcia DA. Laboratory assesment of the anticoagulant activity of direct oral anticoagulants: A systematic rewiew. Chest. 2017;151(1):12735 .

19. van Blerk M, Bailleul E, Chatelain B, et al. Influence of dabigatran and rivaroxaban on routine coagulation assays. A nationwide Belgian survey. Thromb Haemost. 2015; 113: 154-64.

20. Weitz JI, Eikelboom JW. Urgent need to measure effects of direct oral anticoagulants. Circulation. 2016; 134: 186-8.

21. Douxfils J, Mullier F, Robert S, Chatelain C, Chatelain B, Dogn_eJM. Impact of dabigatran on a large panel of routine or specific coagulation assays. Laboratory recommendations for monitoring of dabigatran etexilate. Thromb Haemost. 2012; 107: 985-97.

22. Levy JH, Ageno W, Chan NC, et al. When and how to use antidotes for the reversal of direct oral anticoagulants: guidance from the SSC of the ISTH. J Thromb Haemost. 2016; 14: 623-7.

23. Douxfils J, Mullier F, Loosen C, Chatelain C, Chatelain B,Dogn_e JM. Assessment of the impact of rivaroxaban on coagulation assays: laboratory recommendations for the monitoring of rivaroxaban and review of the literature. Thromb Res. 2012;130:956-66.

24. Douxfils J, Chatelain C, Chatelain B, Dogn_e JM, Mullier F.Impact of apixaban on routine and specific coagulation assays: apractical laboratory guide. Thromb Haemost. 2013;110:283-94.

25. Lippi G, Favaloro EJ. Recent guidelines and recommendations for laboratory assessment of the direct oral anticoagulants (DOACs): is there consensus? Clin Chem Lab Med 2015;53:185-97.

26. Lippi G, Plebani M. Laboratory economics. Risk or opportunity? Clin Chem Lab Med 2016;54:17013.

27. Adam Cuker, Deborah M. Siegal, Mark A. Crowther, David A. Garcia. Laboratory measurement of the anticoagulant activity of the non-vitamin K oral anticoagulants. JACC. 2014; 64(11):1128-39. 
28. Michels WM, Grootendorst DC, Verduijn M, et al. Performance of the Cockcroft-Gault, MDRD, and new CKD-EPI formulas in relation to GFR, age, and body size. Clin J Am Soc Nephrol. 2010;5:1003-9.

29. Child CG, Turcotte JG. Surgery and portal hypertension. Major Probl Clin Surg. 1964;1:1-85.

30. Pugh RN, Murray-Lyon IM, Dawson JL, Pietroni MC, Williams R. Transection of the oesophagus for bleeding oesophageal varices. Br J Surg. 1973;60(8):646-9.

31. Favaloro EJ, et al. Pre-analytical Variables in Coagulation Testing Associated With Diagnostic Errors in Hemostasis. Lab Medicine 2012; 43 (2): 1-10.

32. Favaloro EJ, et al. Laboratory investigation of thrombophilia: The good, the bad, and the ugly. Semin Thromb Hemost. 2009;35:695-710.

33. Tripodi A. Interference of new oral anticoagulants with frequently used coagulation tests. Clin Chem Lab Med. 2012; 50: 1501-3.

34. Moore GW. Recent guidelines and recommendations for laboratory detection of lupus anticoagulants. Semin Thromb Hemost 2014; 40: 163-71.

35. Tripodi A, et al. Position Paper on laboratory testing for patients on direct oral anticoagulants. A Consensus Document from the SISET, FCSA, SIBioC and SIPMeL. Blood Transfus 2018; 16: 46270 . 


\title{
Praktični aspekti u određivanju antikoagulantnog dejstva direktnih oralnih antikoagulantnih lekova
}

\author{
Violeta Dopsaj ${ }^{1,2}$ \\ ${ }^{1}$ Univerzitet u Beogradu - Farmaceutski fakultet, Katedra za madicinsku biohemiju, \\ 11221 Beograd, Srbija \\ ${ }^{2}$ Centar za medicinsku biohemiju, Klinički centar Srbije, 11000 Beograd, Srbija
}

Autor za korespondenciju: Violeta Dopsaj, e-mail: violeta.dopsaj@gmal.com

\begin{abstract}
Kratak sadržaj
Nova generacija oralnih antikoagulantnih lekova omogućava direktnu inhibiciju FIIa ili FXa, i sve više zamenjuje klasične antikoagulanse u kliničkoj praksi za različita stanja. Ovi lekovi su označeni sa nekoliko akronima, uključujući NOAC, DOAC, i odnose se na nove (ne-vitamin $\mathrm{K}$ antagoniste) i direktne oralne antikoagulanse, a trenutno uključuju dabigatran (FIIa inhibitor), i rivaroksaban, apiksaban i edoksaban (FXa inhibitori) . Direktni oralni antikoagulantni lekovi odobreni su za prevenciju moždanog udara kod pacijenata sa ne-valvularnom atrijalnom fibrilacijom i za prevenciju i lečenje venskog tromboembolizma. „Mantra” da direktni oralni antikoagulantni lekovi ne zahtevaju laboratorijsko praćenje ne može se prihvatiti u mnogim kliničkim situacijama. Štaviše, pošto ovi lekovi „ne zahtevaju” laboratorijsko praćenje, neki kliničari su to prihvatili kao da ne utiču na testove $u$ hemostazi. Postoji više situacija u kojima je potrebno rutinsko i hitno određivanje DOAC-a, pri čemu će se broj laboratorijskih zahteva povećavati u budućnosti jer sve više zamenjuju konvencionalne antikoagulanse za sve veći broj indikacija, kod sve većeg broja pacijenata. Glavni cilj ovog rada je da odgovori na praktična pitanja u opštem laboratorijskom ispitivanju DOAC-a, kao i da pomogne u uklanjanju i smanjenju dijagnostičkih grešaka povezanih sa ispitivanjem hemostaze. Testovi za kvantifikaciju DOAC-a moraju biti dostupni u medicinskim centrima 24 sata, kako bi se olakšalo optimalno lečenje u uslovima kada stvari pođu po zlu ili u hitnim slučajevima trenutnog ukidanja antikoagulantne terapije ili odgovarajuće primene specifičnog antidota.
\end{abstract}

Ključne reči: DOAC, rivaroksaban, dabigatran, apiksaban, laboratorijsko praćenje 